\title{
Antibacterial Activity of Weissella confusa Isolated From Vaginal Swab of Indian Women
}

\author{
S. Das Purkhayastha ${ }^{1,2}$, M. K. Bhattacharya ${ }^{1 *}$, Himanshu K. Prasad ${ }^{2}$, H.Upadhyaya ${ }^{3}$, S. Das Lala ${ }^{4}$, \\ K. $\mathrm{Pal}^{5}$, G. D. Sharma ${ }^{2,6}$
}

\begin{abstract}
Weissella confusa, a lactic acid producing bacteria (LAB), is known to occur in the human samples of breast milk, vaginal fluids, saliva and faeces. The species is known to be a probiotic microorganism due to its ability to control the growth of the pathogenic microbes capable of causing food borne diseases. The isolate reported in this study showed high antimicrobial activity against Bacillus subtilis (MTCC 736), Escherichia coli (MTCC 9492), Pseudomonas aeruginosa (MTCC 3541), Proteus mirabilis (MTCC 425), Proteus vulgeris (MTCC 771) and Staphylococcus aureus (MTCC 3160). Additionally, the isolated microbe was resistant to many of the commonly used antibiotics and hence can be used to develop formulations. Thus, the isolated organism may be explored as a probiotic candidate by local administration via suppositories for the prevention and treatment of vaginal infections.
\end{abstract}

Keywords- Antibiotic susceptibility, Probiotic, Vaginal microbiota, Weissella confusa.

\section{INTRODUCTION}

Weissella belongs to lactic acid producing bacteria (LAB) group. They are placed under Firmicutes, class Bacilli, order Lactobacillales and family Leuconostocaceae. They are obligate heterofermentative organisms which produce $\mathrm{CO}_{2}$ from carbohydrate metabolism with lactic acid and acetic acid as major end products.

This microbe is present in nutrient-rich habitats, generally associated with the human body [1] . It has been successfully isolated from human breast milk [2], human saliva [3], human feces [4], and human vagina [5, 7]. Weissella confusa has been so far reported from human feces [8-10].

Two Weissella spp., namely, Weissella viridesens and Weissella Kimchii were reported from women of South Africa [7] and Korea [5]. From the phylogenetic analysis of Weissella kimchii strains, it is suggested to include both Weissella confusa and Weissella cibaria [6]. In a screening test which involved $100 \mathrm{LAB}$ strains, Weissella kimchii

\footnotetext{
${ }^{1}$ Dept. of Botany and Biotechnology, Karimganj College, Karimganj788710 Assam, India

2 Dept. of Life Science and Bioinformatics Assam University, Silchar788011, Assam, India

${ }^{3}$ Department of Botany, Cotton College State University, Guwahati781001 India

${ }^{4}$ Dept. of Biotechnology and Medical Engineering, NIT Rourkela, Rourkela-769008, Orissa, India

${ }^{5}$ BilaspurUniversity, Bilaspur-495001, Chhattisgarh, India

${ }^{6}$ Department of Gynaecology, Hospital of Red cross Society, Karimganj788710, Assam, India

*Corresponding author: - mrinalkxj@yahoo.co.in
}

PL9023 was found to produce highest quantity of hydrogen peroxide [11] and therefore it inhibited growth of pathogenic microbes, namely, Candida albicans, Escherichia coli, Staphylococcus aureus and Streptococcus agalactiae, isolated from the vaginal smears. The presence of surface glycoproteins in W. kimchii PL9023 promoted the adherence of the microbe on the vaginal surface. Further, W. kimchii PL9023 was found to produce no harmful metabolites or enzymes. Based on the results obtained, W. kimchii PL9023 was reported to have a great potential as probiotics for vaginal health. The presence of Weissella confusa as a part of the normal vaginal flora opens up possibility for using this organism as probiotic supplement in female genital tract.

The present paper makes the first report of isolation of Weissella confusa from the vaginal swabs of the woman of North Eastern region of India. Further, the antimicrobial activity of the isolated microbe was tested against Gram positive and Gram negative bacteria, viz., Bacillus subtilis (MTCC 736), Escherichia coli (MTCC 9492), Pseudomonas aeruginosa (MTCC 3541), Proteus mirabilis (MTCC 425), Proteus vulgeris (MTCC 771) and Staphylococcus aureus (MTCC 3160). It further presents antibiotic sensitivity test conducted against the test organisms using twelve antibiotics.

\section{MATERIALS AND METHODS}

\section{A. Sample Collection}

Vaginal samples were collected from the Red Cross Hospital, Karimganj, Assam after obtaining a written informed consent of the volunteers. Prior permission was obtained from the Institutional Ethical Committee, Karimganj College (Memo No. KC/IEC/2012/M-1/10, dated: 23 Jun 2012) for conducting the study. The vaginal swabs were collected by a senior gynaecologist of the Hospital. The participants were explained in local language the procedure and the purpose of the collection of the samples. The volunteers were in the age group of 18-30 years. They were all pre-menopausal, nonmenstrual and either pregnant or non-pregnant. Women suffering from any vaginal disease were not included in the study. Sampling was done using a sterile swab (HiMedia laboratory Pvt. Ltd., India) from the posterior zone of the fornix of the vagina. The swabs containing the vaginal isolates were immediately transferred to the laboratory and were used for the cultivation of bacteria. The pure cultures were stored at $-20{ }^{\circ} \mathrm{C}$ and $-80{ }^{\circ} \mathrm{C}$ as glycerol stock for further use. The 
isolates were characterized for morphological traits and biochemical properties [12].

\section{B.Preparation Of Culture Filtrate And Antimicrobial Assay}

The culture filtrates of the microbes were prepared by incubating the selected microbial colonies in MRS broth (HiMedia Laboratory Pvt. Ltd., India) at $37{ }^{\circ} \mathrm{C}$ for $48 \mathrm{~h}$. After the incubation period, the microbial cells were collected by centrifugation $\left(7000 \mathrm{~g}, 4{ }^{\circ} \mathrm{C}, 10 \mathrm{~min}\right)$. Subsequently, the supernatant was collected and filter sterilized using membrane filter (pore size: $0.22 \mu \mathrm{m}$ ) [13] . Antibacterial assay of the crude bacteriocin was done by agar well diffusion method. For the purpose, Müeller-Hinton agar plates were prepared and the plates were seeded with the test organisms. The standardization of the inoculum density was done using 0.5 McFarland standards. $5 \mathrm{~mm}$ wells were prepared in each Müeller-Hinton agar plates. $50 \mu 1$ of the crude bacteriocin was loaded in each well [14]. The plates were incubated for $24 \mathrm{~h}$ at $37^{\circ} \mathrm{C}$. The isolates which showed antibacterial activities were used for the further study (Table 1).

\section{Characterization Of Antimicrobial Substances}

The bacterial strains were grown on $25 \mathrm{ml}$ of MRS broth at $37^{\circ} \mathrm{C}$ for overnight. Thereafter, the cultures were centrifuged (7000 g, $\left.4{ }^{\circ} \mathrm{C}, 10 \mathrm{~min}\right)$. The supernatant of each strain were divided into equal portions ( $5 \mathrm{~mL}$ each) for different assays. For the bacteriocin assay, the supernatant was treated with proteinase $1 \mathrm{mg} / \mathrm{ml}$ (HiMedia). The supernatant was adjusted to $\mathrm{pH} 6.5 \pm 1$ using $1 \mathrm{~N} \mathrm{NaOH}$ for the organic acid assay, whereas, the culture filtrate was treated with $0.5 \mathrm{mg} / \mathrm{ml}$ catalase (HiMedia) for the hydrogen peroxide assay. The treated supernatants were filter sterilized through $0.22 \mu \mathrm{m}$ syringe filter (HiMedia). Antimicrobial assay was done by agar well diffusion assay as described above against E. coli (MTCC 9492).

\section{Antibiotics susceptibility test}

Antibiotics susceptibility test was done on Müeller-Hinton agar plates. The plates were seeded with Weissella confusa and positive control (Lactobacillus fermentum, a strain which is known to have sensitivity to some of the selected antibiotics). Antibiotics discs of different concentrations were put over the medium at a gap of $40 \mathrm{~mm}$. The plates were incubated for $24 \mathrm{~h}$ at $37^{\circ} \mathrm{C}$.

\section{E. Molecular characterization}

The isolation of the microbial genomic DNA was done as per the method described by Vural and Ozgun (2011) [15] with some modifications. $5 \mathrm{ml}$ of MRS broth was inoculated with the isolates and incubated for $48 \mathrm{~h}$. The broth was centrifuged at $7000 \mathrm{~g}$ at $4{ }^{\circ} \mathrm{C}$ for $10 \mathrm{~min}$. The supernatant was discarded. The cell pellets were treated with $567 \mu \mathrm{l}$ of $1 \mathrm{X}$ TE buffer (Hi Media Laboratory Pvt. Ltd., India) and $2 \mu 1$ of 20 $\mathrm{mg} / \mathrm{ml}$ lysozyme (HiMedia Laboratory Pvt. Ltd., India). Subsequently, the treated cells were incubated for $30 \mathrm{~min}$ (37 ${ }^{\circ} \mathrm{C}$ ) in a shaking water-bath (NSW-133, NSW Pvt Ltd., India). To this mixture, $3 \mu \mathrm{l}$ of each $1 \%$ SDS and $20 \mathrm{mg} / \mathrm{ml}$ proteinase
K (Hi Media Laboratory Pvt. Ltd., India) solutions were added and further incubated for $15 \mathrm{~min}$ at $37{ }^{\circ} \mathrm{C}$. Thereafter, $1 \mu \mathrm{l}$ of 5 $\mathrm{M} \mathrm{NaCl}$ was added and further incubated for $10 \mathrm{~min}$ at $65^{\circ} \mathrm{C}$. Thereafter, $675 \mu$ l of chloroform: isoamyl alcohol (24:1) mixture was added and centrifuged at 10,000 rpm for $5 \mathrm{~min}$ (Centrifuge 5418R, Eppendorf Pvt. Ltd., Germany). The supernatant (aqueous phase) was collected in a fresh tube and an equal volume of phenol: chloroform: isoamyl alcohol (25:24:1) mixture (Hi Media Laboratory Pvt. Ltd. India) was added and centrifuged at $10,000 \mathrm{rpm}$ for $5 \mathrm{~min}$. The supernatant (aqueous phase) was again transferred in a fresh tube, sixth volume of ice-cold isopropanol was added and centrifuged at $10000 \mathrm{rpm}$ for $5 \mathrm{~min}$. The supernatant was discarded and the pellet was washed with $500 \mu \mathrm{l}$ of $70 \%$ alcohol and centrifuged at $5000 \mathrm{rpm}$ for $2 \mathrm{~min}$. The centrifuge tubes were dried and the pellets were dissolved in $20 \mu \mathrm{l}$ of nuclease-free water. The concentration of DNA was measured in BioSpectrometer (Eppendorf Pvt. Ltd., Germany). If the concentration of DNA was $>30 \mathrm{ng} / \mu \mathrm{l}$, the samples were considered for PCR amplification. For identification of the isolate, 16S rRNA gene was amplified using universal primers 27s Forward primer (5'-AGAGTTTGATCMTGGCTCAG-3') and 1492R Reverse primer (5'GGTTACCTTGTTACGACTT-3') [16]. Each single reaction mixture $(10 \mu \mathrm{l})$ contained $1 \mu \mathrm{l}$ of template DNA, $1 \mu \mathrm{l}$ of each primer $(20 \mathrm{pM}), 5 \mu \mathrm{l}$ of Master Mix 2X (HiMedia Laboratory Pvt. Ltd., India) and $2 \mu 1$ of nuclease-free water. The PCR reactions were run under the following conditions: initial denaturation at $94{ }^{\circ} \mathrm{C}$ for $2 \mathrm{~min}, 35$ cycles of $94{ }^{\circ} \mathrm{C}$ for $30 \mathrm{sec}$, $47{ }^{\circ} \mathrm{C}$ for $30 \mathrm{sec}, 72{ }^{\circ} \mathrm{C}$ for $1 \mathrm{~min}$, and final extension at $72{ }^{\circ} \mathrm{C}$ for $3 \mathrm{~min}$ in S1100 thermal cycler (BioRad, USA). The PCR products were visualized in $1 \%$ agarose gel and image was taken by Gel DOC (BioRad, USA).

\section{RESULTS}

Weissella confusa is a Gram positive, catalase negative coccobacilli which do not form endospore. It is a facultative anaerobic bacterium which is cultivated on MRS agar in aerobic condition. The bacterium has been isolated from pregnant women along with Klebsiella pneumoniae. The 16S rRNA gene sequencing and subsequent analysis with bioinformatics tool (BLASTn of NCBI) showed that the bacteria exhibit $100 \%$ similarity with Weissella confusa. The sequence has been submitted in by BanqIt submission tool of NCBI and accession number (Table 1) was obtained.

In the present experiment, the antimicrobial activity of Weissella confusa was studied using $\mathrm{pH}$-adjusted supernatant (Table 2). The activity was tested against pathogenic microorganisms, viz., Bacillus subtilis (MTCC 736), Escherichia coli (MTCC 9492), Pseudomonas aeruginosa (MTCC 3541), Proteus mirabilis (MTCC 425), Proteus vulgaris (MTCC 771) and Staphylococcus aureus (MTCC 3160). It has been found that the highest inhibition zone was produced against Pseudomonas aeruginosa $(16 \mathrm{~mm})$ followed by Proteus mirabilis (15mm), Escherichia coli (12mm), 
Bacillus subtilis $(11 \mathrm{~mm})$ and Staphylococcus aureus $(11 \mathrm{~mm})$. No antibacterial activity was observed against Proteus vulgaris.

The antimicrobial property is due to the production of hydrogen peroxide, bacteriocin- like particles (BLP) and acids. It has been observed that the zone of inhibition is varied when one or more than one inhibitory compound is neutralized as compared to the inhibition size of raw bacteriocin without neutralization of inhibitory substances.

Antibiotic resistance of probiotic microorganism does not pose a safety threat in itself. It is believed that some beneficial microbes, with intrinsic antibiotic resistance, are often successful when both antibiotic and probiotic are used concurrently. This help in the immediate replenishment of the probiotic flora after the antibiotic treatment. Unfortunately, they may form a reservoir of resistance genes for the potential pathogenic microorganisms and hence may constitute a safety threat. In the present experiment, antibiotic sensitivity test was done using Lactobacillus fermentum (positive control). It has been found that the Lactobacillus fermentum is sensitive to amoxicillin (AMP), amoxyclav (AMP), chloramphenicol (C), co-trimoxzole (COT), norfloxacin (NX), streptomycin (HLS) and vancomycin (VA). However, the test organism (Weissella confusa) is resistant to all antibiotics except ciprofloxacin (CIP) and streptomycin (HLS).

\section{DISSCUSSIONS}

In the present paper, Weissella confusa has been reported for the first time from the vaginal swabs of the North-Eastern region of India. It has been generally agreed that Weissella confusa grow in different ecological habitat but it is more commonly found in sugarcane juice, milk, fermented foods and human samples [17]. It has already been stated that Weissella kimchi PL9023 is a potential probiotic for women because the species produces high amount of hydrogen peroxide $\left(\mathrm{H}_{2} \mathrm{O}_{2}\right)$ amongst most of the LAB and it has been reported that the species inhibit the growth and the adherence of the vaginal isolates of Candida albicans, Escherichia coli, Staphylococcus aureus and Streptococcus agalacitiae [11]. According to the said study, Weissella kimchi did not produce harmful metabolites or enzyme and hence was considered as a ppotential probiotic for vaginal health. Others have also hinted that Weissella confusa strains are excellent probiotic agents and require application studies [18]. In the said study, Weissella confusa 20 showed a very high adherence to the caco-2 cells even better than Lactobacillus rhamnasus GG. This character would be very useful for vaginal application of this species. It has been reported that there is bacteriocin like activity (BLA) of Weissella confusa, which can control the growth of food-borne pathogens including Bacillus cereus [19]. Like previous studies, in the present study, a high degree of antibacterial activity of Weissella confusa was observed. Thus, the result obtained in the present experiment is in conformity with the earlier reports published by the different authors.
The isolation of Weissella confusa for the first time from the vaginal swabs of Indian women indicates that it is a resident microorganism in human vagina. It may also be pointed out that Weissella confusa was earlier isolated from human vagina [5]. This microorganism is considered as a safe probiotic agent, although, there are some clinical cases where Weissella confusa was found to be an opportunistic pathogen. Needless to say that the disease caused by this microorganism should be more carefully studied before recognizing it as a probiotic agent [20]. Some authors have reported the occurrence of Weissella confusa in association with Klebsiella pneumonia [21]. However, they could not explain the significance of occurrence of these two microorganisms together. In the present study too, these two microorganisms were reported from the same volunteers. It is possible that, when human vagina is invaded by the microbes which are not the normal inhabitant of the dynamic ecosystem, the body reaction facilitates the growth of microorganisms which perform the immune protective function.

\section{ACKNOWLEDGMENTS}

The authors acknowledge the volunteers for their involvement in this study. Authors also acknowledge the financial assistance from DBT under NER TWINNING PROJECT ( vide DBT Sanction Order No. BT/220/NE/TBP/2011; 30 May, 2012 ). The infrastructural facility created through DBT sponsored Institutional Biotech Hub project (BCIL/NER-BPMC/2010; 30 November, 2010) is also acknowledged.

\section{REFERENCES}

[1] Makarova, K., Slesarev, A., Wolf, Y., Sorokin, A., Mirkin, B., Koonin, E., etal. (2006).Comparative genomics of the lactic acid bacteria. Proc. Natl. Acad. Sci.U.S.A.103,15611-15616.doi:10.1073/ pnas. 0607117103

https://doi.org/10.1073/pnas.0607117103.

[2] Nistal, E., Caminero, A., Vivas, S., Ruizde Morales, J.M., SáenzdeMiera, L. E., Rodríguez-Aparicio, L.B., etal. (2012). Differences in faecal bacteria populations and faecal bacteria metabolism in healthy adults and celiac disease patients. Biochimie94,1724-1729.doi:10.1016/j.biochi.2012.03.025. https://doi.org/10.1016/j.biochi.2012.03.025

[3] Kang, M.-S., Lim, H.-S., Kim, S.-M., Lee, H.-C., and Oh, J.S.,(2011).Effect of Weissella cibariaon Fusobacteriumnucleatum induced interleukin-6 and interleukin- 8 production in KBcells. $J$. Bacteriol. Virol. 41,9-18.doi: 10.4167/jbv.2011.41.1.9. https://doi.org/10.4167/jbv.2011.41.1.9

[4] Wang, C., Zhang, C.W., Chen, H.C., Yu, Q. Pei, X.F., and Liu, H.C. (2008). Phy- logeny analysis and identification of two bacterial strains sourcing from human intestine and having resistance to acid and bile. Sichuan Da XиеХиеBao Yi Хие Ban 39, 263-268.Lee,

[5] J.S., Heo, G.Y., Lee, J.W., Oh, Y.J., Park, J.A., Park, Y.H., et al. (2005). Analysis of kimchi microflora using denaturing gradient gel electrophoresis. Int.J. Food Microbiol. 102,143150.doi:10.1016/j.ijfoodmicro.2004.12.010. https://doi.org/10.1016/j.ijfoodmicro.2004.12.010

[6] Jin, L., Tao, L., Pavlova, S. I., So, J.S., Kiwanuka, N., Namukwaya, Z., etal. (2007). Species diversity and relative eabundance of vaginal lactic acid bacteria from women in Uganda and Korea. J. Appl. Microbiol. 102,1107-1115.doi: 10.1111/j.1365-2672.2006.03147.x. https://doi.org/10.1111/j.1365-2672.2006.03147.x 
[7] Silvester, M.E., and Dicks, L.M. (2003). Identification of lactic acid bacteria isolated from human vaginal secretions. Antonie van Leeuwenhoek 83,117-123. doi:10.1023/A:1023373023115 https://doi.org/10.1023/A:1023373023115

[8] Ponnusamy, K., Choi, J.N., Kim, J., Lee, S.Y., and Lee, C.H. (2011). Microbial community and metabolomics comparison of irritable bowel syndrome faeces. J. Med. Microbiol. 60,817827.doi:10.1099/jmm.0.028126-0 https://doi.org/10.1099/jmm.0.028126-0

[9] Zhang, Z., Peng, X., Zhang, N., Liu, L.,Wang, Y., and Ou, S. (2014). Cytotoxic- ity comparison of quercetin and its metabolites from in vitro fermentation of several gut bacteria. Food Funct. 5, 2152-2156. doi:10.1039/C4FO00418C https://doi.org/10.1039/C4FO00418C

[10] Walter, J., Hertel, C., Tannock, G.W., Lis, C.M., Munro, K., and Hammes, W. P.(2001). Detection of Lactobacillus, Pediococcus, Leuconostoc, and Weissella species in human feces by using groupspecific PCR primers and denaturing gradient gel electrophoresis. Appl. Environ. Microbiol. 67, 2578-2585. doi: 10.1128/AEM.67.6. 25782585. 2001

[11] Lee, Y. (2005). Characterization of Weissella kimchiiPL9023asa potential probiotic for women. FEMS Microbiol. Lett. 250,157-162.doi: 10.1016/j.femsle.2005.07.009

https://doi.org/10.1016/j.femsle.2005.07.009

[12] de Man, J.C., Rogosa, M., and Sharpe, M.E. (1960) A medium for the cultivation of lactobacilli. $J$ of applied Bacteriol. 5 (9), 678-683. https://doi.org/10.1111/j.1365-2672.1960.tb00188.x

[13] Ogunbanwo, S., Sanni, A., and Onlude, A., (2003) Influence of cultural condition on the production of bacteriocin by lactobacillus brevis OG 1 . African J. of Biotechnology, 2(7), 179-184. https://doi.org/10.5897/AJB2003.000-1037

[14] Geis A, Singh J, TeuberM. Potential of lactic streptococci to produce bacteriocin (1983) .ApplEnvironMicrobiol. 45: 205-211.

[15] Vural H. C. and Ozgun D. (2011). An improving DNA isolation method for identification of anaerobic bacteria in human colostrum and faeces samples. Journal of Medical Genetics and Genomics Vol. 3 (5), pp. 95 -100 .

[16] Lane, D. J. (1991) 16S/23S rRNA sequencing. In Nucleic Acid Techniques in Bacterial Systematics. Edited by E. Stackebrandt\& M. Goodfellow. New York: Wiley pp. 115-175.

[17] Kumar, A., Augustine, D., Sudhindran, S., Kurian, A.M., Dinesh, K.R., Karim, S., etal. (2011). Weissella confusa: a rare cause of vancomycinresistant Gram-positive bacteraemia. J. Med. Microbiol. 60,15391541.doi: $10.1099 /$ jmm. 0.027169-0 https://doi.org/10.1099/jmm.0.027169-0

[18] Lee, K. W., Park, J.Y., Jeong, H.R., Heo, H.J., Han, N.S., and Kim, J. H. (2012). Probiotic properties of Weissella strains isolated from human faeces. Anaerobe 18,96-102. doi:10.1016/j.anaerobe. 2011.12.015

[19] Chavasirikunton, Veerapon, SavitriVatanyoopaisarn and ChantarapornPhalakornkule (2006-2007) Bacteriocin-Like activity from Weissella confusa and Pediococcusacidilacticiisolated fromtraditional Thai fermented sausages. Journal Of Culture Collections, Volume 5, 64-72.

[20] Fairfax, M.R., Lephart, P.R., and Salimnia, H. (2014). Weissella confusa: prob- lems with identification of an opportunistic pathogen that has been found in fermented foods and proposed as a probiotic. Front. Microbiol. 5:254.doi: 10.3389 / fmicb.2014.00254 https://doi.org/10.3389/fmicb.2014.00254

[21] Olano, A., Chua, J., Schroeder, S., Minari, A., Lasalvia, M., and Hall, G. (2001). Weissella confusa (Basonym: Lactobacillus confusus) bacteremia: a case report. J. Clin. Microbiol. 39,16041607.doi:10.1128/JCM.39.4.1604-1607.2001 https://doi.org/10.1128/JCM.39.4.1604-1607.2001

TABLE I

ANTIBACTERIAL ACTIVITY OF VAGinAL ISOLATE Which EXHIBITED INHIBITION ZONE AGAINST TEST ORGANISMS

\begin{tabular}{|l|l|l|l|l|l|l|}
\hline \multirow{2}{*}{$\begin{array}{l}\text { Name of the } \\
\text { organisms with }\end{array}$} & \multicolumn{6}{|c|}{ Test organisms (MTCC) } \\
\cline { 2 - 7 } $\begin{array}{l}\text { GENBANK } \\
\text { accession } \\
\text { number }\end{array}$ & $\begin{array}{l}\text { Bacillus } \\
\text { subtilis } \\
(\text { MTCC } \\
736)\end{array}$ & $\begin{array}{l}\text { Escherichia } \\
\text { coli } \\
(\text { MTCC 9492) }\end{array}$ & $\begin{array}{l}\text { Proteus } \\
\text { mirabilis } \\
(\text { MTCC } \\
425)\end{array}$ & $\begin{array}{l}\text { Proteus } \\
\text { vulgeris } \\
(\text { MTCC } \\
771)\end{array}$ & $\begin{array}{l}\text { Pseudomonus } \\
\text { aeruginosa } \\
(\text { MTCC 3541) }\end{array}$ & $\begin{array}{l}\text { Staphylococcus } \\
\text { aureus } \\
\text { 3160) }\end{array}$ \\
\cline { 2 - 7 } & \multicolumn{6}{|c|}{ Inhibition zone in mm (replicates of three) } \\
\hline $\begin{array}{l}\text { Weissella } \\
\text { confusa K75 } \\
\text { KT361205 }\end{array}$ & $11 \pm 1$ & $12 \pm 1.7$ & $15 \pm 1$ & - & $16 \pm 2$ & $11 \pm 1$ \\
\hline $\begin{array}{l}\text { Positive control } \\
\text { (Antibiotics) }\end{array}$ & 28 & 30 & 26 & 28 & 27 & 24 \\
\hline
\end{tabular}

TABLE II

ANTIBIOTICS SUSCEPTIBILITY TEST AGAINST TEST ORGANISM WEISELLA CONFUSA K75 AND L. FERMENTUM, A POSITIVE CONTROL

\begin{tabular}{|c|c|c|c|c|}
\hline \multirow{2}{*}{$\begin{array}{l}\text { Serial } \\
\text { No }\end{array}$} & \multirow[t]{2}{*}{ Name of the Antibiotics } & \multirow{2}{*}{$\begin{array}{l}\text { Quantity in the disc } \\
\text { (mcg/disc) }\end{array}$} & \multicolumn{2}{|c|}{ Zone of inhibition (replicates of three) } \\
\hline & & & $\begin{array}{l}\text { Against } W . \\
\text { confusa K75 }\end{array}$ & $\begin{array}{l}\text { Against Control } \\
\text { (L.fermentum ) }\end{array}$ \\
\hline 1. & Amoxycilin (AMP) & 10 & - & $30 \pm 2$ \\
\hline 2. & Amoxyclav (AMP) & 30 & - & $30 \pm 0.6$ \\
\hline 3. & Chloromphenicol (C) & 30 & - & $10 \pm 0.6$ \\
\hline 4. & Ciprofloxacin (CIP) & 5 & $14 \pm 0.6$ & - \\
\hline 5. & Co-Trimoxzole (COT) & 25 & - & $12 \pm 1$ \\
\hline 6. & Methicillin (MET) & 5 & - & - \\
\hline 7. & Nalidaxic acid (NA) & 30 & - & - \\
\hline
\end{tabular}


Int'l Journal of Advances in Chemical Engg., \& Biological Sciences (IJACEBS) Vol. 4, Issue 1 (2017) ISSN 2349-1507 EISSN 2349-1515

\begin{tabular}{|l|l|l|l|l|}
\hline 8. & Norfloxacin (NX) & 10 & - & $10 \pm 0.6$ \\
\hline 9. & Nitrofurantoin (NIT) & 300 & - & - \\
\hline 10. & Streptomycin (HLS) & 300 & $10 \pm 1.5$ & $15 \pm 1.5$ \\
\hline 11. & Tertracyclin (TET) & 30 & - & - \\
\hline 12. & Vancomycin (VA) & 30 & - & $15 \pm 0.6$ \\
\hline
\end{tabular}

